\title{
ANALISIS PENERIMAAN SISTEM PEMBELAJARAN ONLINE EDMODO MENGGUNAKAN UNIFIED THEORY OF ACCEPTANCE AND USE OF TECHNOLOGY (UTAUT) STUDI KASUS: KELAS IX DI SMP NEGERI 1 SINGARAJA
}

\author{
Sysca Taqwatika ${ }^{1}$, Ketut Agustini ${ }^{2}$, P.Arta Suyasa ${ }^{3}$ \\ Program Studi Pendidikan Teknik Informatika \\ Jurusan Teknik Informatika \\ Fakultas Teknik dan Kejuruan \\ Universitas Pendidikan Ganesha \\ Email : syzcataqawatikat@gmail.com¹, ketutagustini@undiksha.ac.id ${ }^{2}$, artasuyasa@undiksha.ac.id ${ }^{3}$
}

\begin{abstract}
Abstrak-Tujuan dari penelitian ini adalah untuk mengetahui bagaimana penerimaan pengguna terhadap sistem Pembelajaran Online Edmodo sehingga pengembangan sistem layak dilaksanakan. Salah satu pendekatan teori penerimaan dan penggunaan terhadap suatu teknologi yaitu Unified Theory Of Acceptance And Use Of Technology (UTAUT). UTAUT merupakan salah satu model penerimaan teknologi yang dikembangkan oleh Vankatesh, et al. (2003) dengan menggabungkan delapan teori penerimaan teknologi sebelumnya. UTAUT memiliki empat konstruk utama yaitu 1) performance expectancy, 2) effort expectancy, 3) social influence, dan 4) facilitating conditions. Penelitian ini selanjutnya akan menjelaskan tentang hubungan faktorfaktor yang mempengaruhi penerimaan dan penggunaan sistem Pembelajaran Online Edmodo menggunakan model UTAUT. Data diperoleh dengan cara menyebarkan kuesioner tertutup kepada siswa dan wawancara bersama guru dan siswa. Besar sampel pada penelitian ini berjumlah 72 siswa, setalah menyebarkan kuisioner data lalu dianalisis menggunakan Smart PLS Hasil penelitian ini menunjukkan bahwa Variabel Ekpektansi Kinerja berpengaruh positif terhadap minat penggunaan Sedangkan variabel Ekspektasi usaha dan Pengaruh Sosial tidak berpengaruh positif terhadap minat penggunaan Sistem Pembelajaran Online Edmodo. Kondisi yang memfasilitasi berpengaruh positif terhadap perilaku penggunaan Sistem Pembelajaran Online Edmodo.
\end{abstract}

Kata kunci :Pembelajaran Online Edmodo,Siswa, Unified Theory Of Acceptance And Use Of Technology (UTAUT),

Abstract-The study aimed at to find out how the user accepts the Edmodo online learning system could development feasible. One of the approaches to the theory of acceptance and use of a technology is the Unified Theory of Acceptance and use of technology (UTAUT). UTAUT is one of the technology acceptance models developed by Vankatesh, et al (2003) by combining eight previous technology theories. UTAUT has four main constructs: 1 . performance expectancy, 2. effort expectancy, 3. social influence and 4. Facilitating conditions. This research will continuing explain the relationship of the factors that influence the acceptance and use of Edmodo's online learning system using the UTAUT model. Data was obtained by distributing closed questionnaires to students and interviews with teachers and students. The sample size in this study amounted to 72 students, after distributing the data questionnaire and then analyzed using smart PLS. The results of this study indicate that the performance expansion variable has a positive effect on interest in use. Although the business expectation variable and social influence did not have a positive effect on the interest in using the edmodo online learning system. Facilitating conditions have an effect on the positive behavior of using Edmodo's online learning system.

Keyword : Edmodo Online Learning, students Unified Theory Of Acceptance And Use Of Technology (UTAUT),

\section{PENDAHULUAN}

Teknologi informasi dan komunikasi sekarang ini berkembang dengan sangat pesat. Dampak dari perkembangannya juga dapat dirasakan dalam dunia pendidikan, antara lain terciptanya berbagai media pembelajaran berbasis IT yang dapat membantu guru dalam proses pembelajaran. 
Volume 8, Nomor 2, Tahun 2019

SMP Negeri 1 Singaraja sudah banyak yang mengenal akan prestasi dari siswa maupun gurunya, belakangan ini terus menggenjot tingkat pembelajaran di kelas atau pelatihan - pelatihan yang diberikan kepada guru disana. Salah satu trobosan yang diambil oleh pihak sekolah adalah menerapkan sistem pembelajaran online Edmodo berbasis teknologi informasi (TI). Dimana penggunaan sistem Edmodo ini sudah di gunakan dari tahun 2015.akan tetapi sistem edmodo ini hanya untuk guru dan siswa. sehingga masing - masing guru telah di fasilitasi setiap ruang kelas dan terhubung secara online.

Sistem ini diharapkan dapat meningkatkan mutu pendidikan sekolah karena sistem sudah menyediakan materi - materi yang akan diberikan oleh gurunya, selain itu untuk penilaian quiz dan tugas sistem sudah langsung menilai sendiri yang nantinya akan mengeluarkan hasil nilai siswa. Sehingga siswa bisa melihat secara langsung nilai yang diperolehnya (Hendra, 2018).

Namun setelah peneliti melakukan observasi ke sekolah SMP Negeri 1 Singaraja, peneliti menemukan masalah bagi pengguna baik itu siswa maupun guru karena merasa kesulitan harus menggunakan koneksi internet serta fasilitas yang kurang mendukung yang bisa terhubung dengan internet. Mereka kesulitan untuk masuk ke sistem saat sistem mengalami gangguan misalnya ketika koneksi wifi di sekolah bermasalah. Maka sistem pembelajaran online Edmodo akan mengalami kesalahan koneksi dan akan diperlukan waktu yang lebih lama untuk koneksi stabil kembali. Selain itu, pembuatan akun yang menyebabkan siswa kurang berminat untuk melanjutkan masuk ke sistem serta tampilan sistem yang kurang menarik sehingga siswa merasa kurang berminat untuk menggunakan sistem Edmodo. Sementara untuk guru, adanya kesulitan untuk mengunggah materi ajar yang akan digunakan untuk proses belajar siswa. Sehingga dapat mengurangi minat siswa dalam belajar dan pembelajaran menjadi kurang efektif.

Pada Penelitian ini peneliti menggunakan metode UTAUT. UTAUT merupakan salah satu model penerimaan teknologi terkini yang dikembangkan oleh Vankatesh, dkk. UTAUT menggabungkan fitur-fitur dari delapan teori penerimaan teknologi terkemuka menjadi satu teori. Kedelapan teori terkemuka yang disatukan didalam UTAUT adalah theory of reasoned action (TRA), technology acceptance model (TAM), motivational model $(M M)$, theory of palnned behaviour (TPB), combined $T A M$ and TPB, model of PC utilization (MPTU), innovation diffusion theory (IDT) dan social cognativetheory (SCT). Menurut Venkatesh et al. (2003), terdapat empat konstruk utama yang mempengaruhi minat keperilakuan (behavioral intention) dan perilaku menggunakan (use behavior) teknologi informasi, yaitu ekspektansi kinerja (performance expectancy), ekspektansi usaha (effort expectancy), pengaruh sosial (social influence), dan kondisikondisi pemfasilitasi (facilitating conditions) (Mediyanto \& Mahendra,2017).

Berdasarkan hal tersebut, peneliti akan melakukan penelitian tentang "ANALISIS PENERIMAAN SISTEM PEMBELAJARAN ONLINE EDMODO MENGGUNAKAN MODEL UNIFIED THEORY OF ACCEPTANCE AND USE OF TECHNOLOGY (UTAUT) STUDI KASUS: SMP NEGERI 1 SINGARAJA",

\section{KAJIAN PUSTAKA}

\section{A. Kajian Pustaka}

\section{a. E-LEARNING}

Pengembangan E-learning tidak semata-mata hanya menyajikan meteri pelajaran secara on-line saja, namun harus komunikatif dan menarik. Salah satu E-learning platform yang banyak digunakan antara lain Edmodo.

b. Sistem Pembelajaran Online Edmodo

Edmodo merupakan pembelajaran berbasis jejaring sosial yang aman dan gratis dalam memudahkan guru untuk membuat dan mengelola kelas virtual sehingga siswa dapat terhubung dengan teman sekelas dan guru kapan saja dan dimana saja (K. Balasubramanian, V. Jaykumar, and L. Nitin, 2014).

c. Unified Theory Of Acceptance And Use Of Technology (UTAUT)

UTAUT merupakan salah satu model penerimaan teknologi yang dikembangkan oleh [11] dengan menggabungkan fitur-fitur yang berhasil dari delapan teori penerimaan teknologi sebelumnya. Delapan teori tersebut adalah theory of reasoned action (TRA), technology acceptance model (TAM), motivational model (MM), theory of palnned behavior (TPB), Combined TAM and TPB, model of PC utilization (MPTU), innovation diffusion theory (IDT) dan social cognativetheory (SCT) [11]

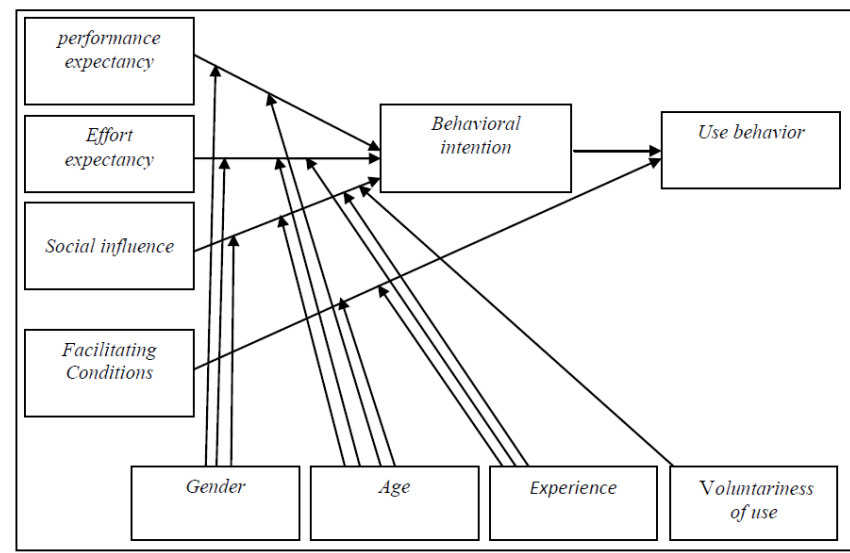

Gambar 1.1 Model Utaut 


\section{d. Penelitian Terkait}

[4] melakukan penelitian menggunakan model Unified Theory Of Acceptance And Use Of Technology yang disesuaikan dengan tujuan penelitian. Secara khusus, model UTAUT disesuaikan berdasarkan keterbatasan dan saran yang dibuat oleh peneliti. Pertama, sikap dimasukkan sebagai variabel independen yang mempengaruhi perilaku pengguna. Kedua, moderator disesuaikan dengan konteks Building Information Modeling (BIM) dan lingkup penelitian itu sendiri dengan menghapus moderator age dan gender.

Penelitian lain oleh [12] yaitu "Penerapan Model Unified Theory Of Acceptance And Use Of Technology di Kota Denpasar" dengan hasil penelitian semua hipotesis penelitian diterima yaitu ekspektasi kinerja, ekspektasi usaha, faktor social dan kondisi yang memfasilitasi mempunyai pengaruh positif yang signifikan pada minat pengguna e-Filling. Hal tersebut memiliki makna bahwa semakin tinggi keyakinan seseorang dengan menggunakan e-Filling akan meningkatkan kinerja dan mengurangi usahanya dalam bekerja maka akan meningkat pula mereka dalam menggunakan e-Filling. Semakin tinggi pengaruh lingkungan social dan tersedianya fasilitas dalam penggunaaan e-Filling maka meningkat pula minat mereka dalam menggunakan e-Filling.

\section{B. Landasan Teori}

a. Populasi dan Sampel Penelitian

Jumlah anggota sampel sering dinyatakan dengan ukuran sampel. Jumlah sampel yang diharapkan 100\% mewakili populasi adalah sama dengan jumlah anggota populasi itu sendiri. Jadi bila jumlah populasi 1000 dan hasil penelitian itu akan diberlakukan untuk 1000 orang tersebut tanpa ada kesalahan, maka jumlah sampel yang diambil sama dengan jumlah populasi tersebut yaitu 1000 orang. Makin besar jumlah sampel mendekati populasi, maka peluang kesalahan generalisasi semakin kecil dan sebaliknya makin kecil jumlah sampel menjauhi populasi, maka makin besar kesalahan generalisasi [10].

b. Skala Pengukuran dan Instrumen Penelitian

Dengan skala likert, maka variabel yang akan diukur dijabarkan menjadi indicator variabel. Kemudian indicator tersebut dijadikan sebagai titik tolak untuk menyusun item-item instrument yang dapat berupa pernyataan atau pertanyaan.

c. Instrumen Penelitian

Instrumen adalah pengukuran terhadap fenomena social maupun alam. Jumlah instrument penelitian tergantung pada jumlah variable penelitian yang telah ditetapkan untuk diteliti [10]

d. Uji Coba Instrumen
Dengan menggunakan instrumen yang valid dan reliabel dalam pengumpulan data, maka diharapkan hasil penelitian akan menjadi valid dan reliabel. Jadi instrumen yang valid dan reliabel merupakan syarat mutlak untuk mendapatkan hasil penelitian y ang valid dan reliable [10].

\section{METODOLOGI PENELITIAN}

Penelitian ini menggunakan pendekatan PLS untuk menganalisis data. Tahap selanjutnya analisis dilakukan dengan menggunakan software SmartPLS.

A. Evaluasi Model Pengukuran (Outer Model)

Model pengukuran atau outer model mendefinisikan bagaimana setiap blok indikator berhubungan dengan konstruk latennya.

B. Model Struktural (Inner Model)

Model strurktural atau inner model mengGambarkan hubungan antar konstruk laten berdasarkan pada teori.

\section{HASIL \& PEMBAHASAN}

A. Hasil Uji Gregory

Pada saat peneliti melakukan uji validitas isi ke penguji uji ahli 1 peneliti hanya direvisi dari kata-kata pernyataan, penguji belum mengisi relevan atau tidaknya suatu pernyataan, lalu peneliti merevisi pernyataan dari penguji penguji ahli, begitupun dengan penguji uji ahli 2 .

B. Uji Validitas

Uji validitas dilakukan untuk mengukur tingkat kevalidan suatu instrument. Pada penelitian ini kuisioner telah diujicobakan ke 30 responden diluar sampel.

Berdasarkan uji validitas yang dilakukan, terdapat 2 buah item pernyataan pada ekspektasi kinerja yang nilai $\mathrm{r}_{\text {hitung }}<\mathrm{r}_{\text {Tabel }}$ sehingga item pernyataan pada ekspektasi kinerja tersebut dihapuskan. Pernyataan yang dihapuskan tersebut yaitu pernyataan nomor 2 menggunakan Sistem Pembelajaran Online Edmodo akan meningkatkan proses belajar saya dan 10 Sistem Pembelajaran Online Edmodo membantu saya dalam melaksanakan proses pembelajaran pernyataan ini dihapus dan tidak digunakan untuk pengambilan data selanjutnya dari variabel Ekspektasi Kinerja.

\section{Uji Reliabilitas}

Berdasarkan kriteria tinggi rendahnya nilai koefisien reliabilitas, nilai cronbach alpha pada instrumen ini berkategori sangat tinggi yaitu $0,91 \leq 0,913<1$. Setelah instrumen selesai diuji cobakan selanjutnya instrumen disebar ke sampel responden yang berjumlah 72 responden

D. Analisis Model Pengukuran (Outer Model)

1. Uji Individual Item Reliability

Nilai dari suatu indikator tersebut dinyatakan valid apabila nilai tersebut diatas 0,7 . Nilai yang dibawah 0,7 
ISSN 2252-9063

Kumpulan Artikel Mahasiswa Pendidikan Teknik Informatika

(KARMAPATI)

harus dihapus dari diagram jalur karena nilai tersebut memilik reabilitas dan validitas yang belum mencukupi [9].

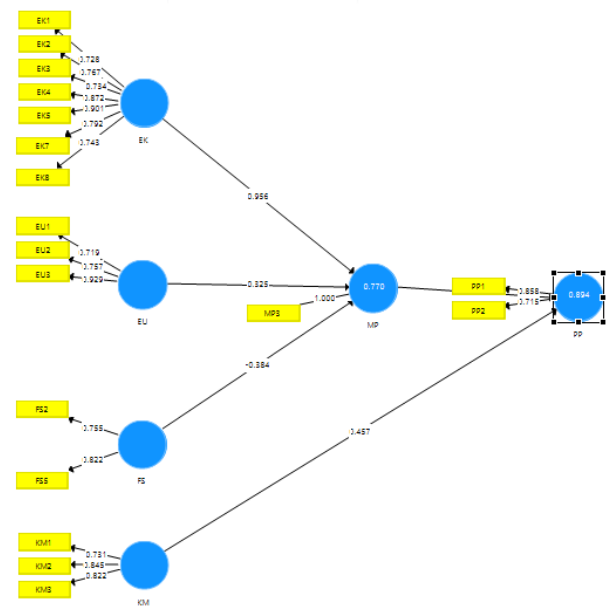

Gambar 1.2

Model Diagram Jalur menggunakan SmartPLS

\section{Uji Internal Consitency Reliability}

Uji Internal Consitency Reliability merupakan gabungan reabilitas indicator ke variable melihat nilai cronbach's alpha dan composite reliability yang minimal nilainya 0,7 [9].

Tabel 1.2

Hasil Uji Internal Consistency Reliability dengan SmartPLS

\begin{tabular}{|l|r|l|}
\hline & \multicolumn{1}{|l|}{$\begin{array}{l}\text { Cronbach's } \\
\text { Alpha }\end{array}$} & $\begin{array}{l}\text { Reliabilitas } \\
\text { Komposit }\end{array}$ \\
\hline Ekspektansi Kinerja & 0.924 & 0.922 \\
\hline Ekspektansi Usaha & 0.855 & 0.847 \\
\hline Faktor Sosial & 0.766 & 0.767 \\
\hline Kondisi Memfasilitasi & 0.840 & 0.842 \\
\hline Minat Penggunaan & 1.000 & 1.000 \\
\hline Perilaku Pengguna & 0.761 & 0.767 \\
\hline
\end{tabular}

3. Uji Average Variance Extracted (AVE)

Pengujian AVE bertujuan untuk menunjukkan ukuran sejauh mana sebuah indicator berkolerasi politik terhadap indicator lain terhadap indicator konstruk yang sama [9].
Tabel 1.1

Hasil Uji Average Variance Extraxted (AVE) dengan SmartPLS

\begin{tabular}{|l|r|}
\hline \multicolumn{1}{|c|}{ Variabel } & (AVE) \\
\hline Ekspektansi Kinerja & $\mathbf{0 . 6 3 0}$ \\
\hline Ekspektansi Usaha & 0.651 \\
\hline Faktor Sosial & 0.623 \\
\hline Kondisi Memfasilitasi & $\mathbf{0 . 6 4 2}$ \\
\hline Minat Penggunaan & 1.000 \\
\hline Perilaku Pengguna & $\mathbf{0 . 6 2 4}$ \\
\hline
\end{tabular}

Berdasarkan hasil pengujian diatas maka dapat disimpulkan bahwa nilai AVE diatas 0,5. Sehingga pengujian dapat dilanjutkan ke langkah selanjutnya.

\section{Uji Disccriminant Validity}

Discriminant Validity diuji pada level indicator dan variable. Pada level indicator tidak ada indicator yang yang memberikan loading ke variable yang lebih tinggi dibandingkan variable yang seharusnya [8] .Berdasarkan hasil dari langkah - langkah setiap pengujian yang ada pada model pengukuran, menunjukan bahwa yang diajukan peneliti mempunyai nilai statistic yang baik. Maka dari itu, dapat diartikan bahwa model tersebut memenuhi syarat untuk dilanjutkan kedalam pengujian struktur model (inner model).

E. Analisis Model Struktural (Inner Model)

1. Asesmen Kolinearitas diuji dengan menggunakan toleransi nilai VIF. Apabila nilai VIF $>=0,5$ maka menunjukkan bahwa dua konstruk tersebut mempunyai persoalan kolinearitas. [9] 
ISSN 2252-9063

Kumpulan Artikel Mahasiswa Pendidikan Teknik Informatika

(KARMAPATI)

Tabel 1.3

Tabel Hasil Uji Asesmen Kolinearitas

\begin{tabular}{|l|r|}
\hline & \multicolumn{1}{|l|}{ VIF } \\
\hline EK1 & 6.352 \\
\hline EK2 & 2.827 \\
\hline EK3 & $\mathbf{7 . 3 5 2}$ \\
\hline EK4 & 2.385 \\
\hline EK5 & 2.379 \\
\hline EK7 & 2.803 \\
\hline EK8 & 2.022 \\
\hline EU1 & 4.652 \\
\hline EU2 & 4.119 \\
\hline EU3 & 1.549 \\
\hline FS2 & 1.626 \\
\hline FS5 & 1.626 \\
\hline KM1 & 1.716 \\
\hline KM2 & 2.317 \\
\hline KM3 & 2.207 \\
\hline MP3 & 1.000 \\
\hline PP1 & 1.605 \\
\hline PP2 & 1.605 \\
\hline
\end{tabular}

Berdasarkan tabel diatas, hasil nilai kolinieritas yang dilihat dari VIF tidak ada nilai yang lebih dari 5 sehingga indikator tersebut tidak mempunyai persoalan kolinearitas.

2. Koefesien Jalur

Koefesien jalur mempunyai nilai terstandarisasi antara nilai -1 dan +1 . Nilai koefesien jalur yang mendekati +1 menunjukkan adanya relasi positif yang sangat kuat dari variable yang direlasikan. Nilai yang mendekati -1 menunjukkan adanya relasi negative yang sangat kuat. Jika koefesien jalur mempunyai nilai yang menjauhi nol biasanya signifikan secara statis [9]
Tabel 1.4

Tabel Hasil Uji Asesmen Kolinearitas

\begin{tabular}{|c|c|c|}
\hline & $\begin{array}{l}\text { Minat } \\
\text { Penggunaan }\end{array}$ & $\begin{array}{l}\text { Perilaku } \\
\text { Penggunaan }\end{array}$ \\
\hline $\begin{array}{l}\text { Ekspektansi } \\
\text { Kinerja }\end{array}$ & 0.956 & \\
\hline $\begin{array}{l}\text { Ekspektansi } \\
\text { Usaha }\end{array}$ & 0.325 & \\
\hline Faktor Sosial & -0.384 & \\
\hline $\begin{array}{l}\text { Kondisi } \\
\text { Memfasilitasi }\end{array}$ & & 0.457 \\
\hline $\begin{array}{l}\text { Minat } \\
\text { Penggunaan }\end{array}$ & & 0.585 \\
\hline $\begin{array}{l}\text { Perilaku } \\
\text { Pengguna }\end{array}$ & & \\
\hline
\end{tabular}

Berdasarkan hasil pengujian koefesien jalur menunjukkan hasil bahwa semua nilai koefesien jalur menjauhi 0 yang berarti nilai koefesien jalur tersebut signifikan

3. Koefesien Determinasi

Koefesien determinasi menunjukkan kombinasi pengaruh pengaruh variable bebas ke variable terikat. Nilai $R$-Square berkisar antara 0 sampai 1 dengan nilai yang mendekati 1 menunjukkan akurasi prediksi semakin besar [9]

Tabel 1.5

Hasil Pengujian $R$-Squere

\begin{tabular}{|l|r|rr|}
\hline & \multicolumn{1}{|l|}{$\begin{array}{l}\text { R } \\
\text { Square }\end{array}$} & \multicolumn{1}{|l|}{$\begin{array}{l}\text { R Square } \\
\text { Adjusted }\end{array}$} & \\
\hline $\begin{array}{l}\text { Minat } \\
\text { Penggunaan }\end{array}$ & 0.770 & & 0.760 \\
\hline $\begin{array}{l}\text { Perilaku } \\
\text { Penggunaan }\end{array}$ & 0.894 & & 0.891 \\
\hline
\end{tabular}

Berdasarkan nilai R-square yang diperoleh hasil analisis variabel minat penggunaan adalah 0,770 yang berarti bahwa variabel Minat Penggunaan dapat dijelaskan sebesar $77 \%$ oleh variabel ekspektasi kinerja, ekspektasi usaha, pengaruh sosial. Nilai R-Square pada variabel perilaku pengguna adalah sebesar 0,894 yang berarti variabel ini dapat dijelaskan sebesar $85,4 \%$ oleh variabel Minat Penggunaan dan kondisi yang memfasilitasi.

\section{PEMBAHASAN}

Signifikansi parameter outer model dapat dievaluasi melalui prosedur resampling bootstrapping dengan tingkat signifikansi $\alpha$ yang digunakan adalah $5 \%$, sehingga nilai ttabel adalah sebesar 1,96 [12]. 
Tabel 1.6

Hasil Pengujian Hipotesis

\begin{tabular}{|l|r|r|r|r|r|}
\hline & $\begin{array}{l}\text { Original } \\
\text { Sample } \\
(\mathbf{O})\end{array}$ & $\begin{array}{l}\text { Sample } \\
\text { Mean } \\
(\mathbf{M})\end{array}$ & $\begin{array}{l}\text { Standard } \\
\text { Deviation } \\
\text { (STDEV) }\end{array}$ & $\begin{array}{l}\text { T Statistics } \\
(\mid \mathbf{O} / \text { STDEV })\end{array}$ & $\begin{array}{l}\text { P } \\
\text { Values }\end{array}$ \\
\hline $\begin{array}{l}\text { EK - } \\
\text { > MP }\end{array}$ & 0.438 & 0.421 & 0.168 & 2.609 & 0.009 \\
\hline $\begin{array}{l}\text { EU -> } \\
\text { MP }\end{array}$ & 0.229 & 0.253 & 0.156 & 1.475 & 0.141 \\
\hline $\begin{array}{l}\text { FS -> } \\
\text { MP }\end{array}$ & 0.242 & 0.237 & 0.130 & 1.861 & 0.063 \\
\hline $\begin{array}{l}\text { KM - } \\
\text { > PP }\end{array}$ & 0.334 & 0.340 & 0.078 & 4.315 & 0.000 \\
\hline $\begin{array}{l}\text { MP - } \\
\text { > PP }\end{array}$ & 0.577 & 0.574 & 0.066 & 8.739 & 0.000 \\
\hline
\end{tabular}

\section{PEMBAHASAN HASIL PENELITIAN}

\section{a. Pengaruh Ekspektasi Kinerja terhadap Minat Penggunaan Sistem Pembelajaran Online Edmodo \\ Ekspektasi kinerja mempunyai nilai $t$ -} stastistics sebesar 2,609 yang berarti nilai tersebut diatas nilai t-tabel 1,96. Nilai p-values variabel ekspektasi kinerja $(0,009<0,05)$ sesuai hasil tersebut berarti ekspektasi kinerja berpengaruh positif terhadap Minat Penggunaan. Ini bahwa Ekspektasi kinerja ini berkaitan dengan persepsi pengguna terhadap kegunaan, motivasi ekstrinsik penggunaan sistem, kesesuaian pekerjaan terhadap sistem, keuntungan relative menggunakan sistem dan ekspektasi hasil

Berdasarkan tabel hasil pengujian hipotesis yang dilakukan didapatkan hasil pembahasan sebagai berikut:

1. Hipotesis pertama $\left(\mathrm{H}_{1}\right)$ yaitu terdapat pengaruh positif antara Ekspektasi Kinerja terhadap Minat Penggunaan Sistem Pembelajaran Online Edmodo. Hipotesis ini diterima karena nilai t-statistics variabel Ekspektasi Kinerja terhadap variabel Minat Penggunaan lebih besar dari nilai t-tabel $(1,96)$ yaitu 2,609

2. Hipotesis kedua $\left(\mathrm{H}_{2}\right)$ yaitu terdapat pengaruh positif antara Ekspektasi Usaha terhadap Minat Penggunaan Sistem Pembelajaran Online Edmodo.. Hipotesis ini ditolak karena nilai $t$-statistics variabel Ekspektasi Usaha terhadap variabel Minat Penggunaan lebih kecil dari nilai t-tabel $(1,96)$ yaitu 1,475

3. Hipotesis ketiga $\left(\mathrm{H}_{3}\right)$ yaitu terdapat pengaruh positif antara Pengaruh Sosial terhadap terhadap Minat Penggunaan Sistem Pembelajaran Online Edmodo. Hipotesis ini ditolak karena nilai $t$ statistics variabel Pengaruh Sosial terhadap variabel Minat Penggunaan lebih besar dari nilai t-tabel $(1,96)$ yaitu 1,861

4. Hipotesis keempat $\left(\mathrm{H}_{4}\right)$ yaitu terdapat pengaruh positif antara Kondisi yang Memfasilitasi terhadap terhadap Minat Penggunaan Sistem Pembelajaran Online Edmodo. Hipotesis ini diterima karena nilai t-statistics variabel Kondisi yang Memfasilitasi terhadap variabel Perilaku Pengguna lebih besar dari nilai t-tabel $(1,96)$ yaitu 4,315

5. Hipotesis kelima $\left(\mathrm{H}_{5}\right)$ yaitu terdapat pengaruh positif antara Minat Penggunaan terhadap Perilaku Pengguna Sistem Pembelajaran Online Edmodo.. Hipotesis ini diterima karena nilai t-statistics variabel Minat Penggunaan terhadap variabel Perilaku Pengguna lebih besar dari nilai t-tabel $(1,96)$ yaitu 8,739 . ketika pengguna menggunakan sistem tersebut. Berdasarkan hasil kuisioner yang disebarkan oleh peneliti diperoleh hasil pengukuran pada variabel ekspektasi kinerja Sistem Pembelajaran Online Edmodo yaitu sebanyak 17,3\% pengguna sangat setuju, 24,6\% pengguna setuju, 12,3\% pengguna menjawab netral, dan $3,4 \%$ pengguna menjawab kurang setuju. Variabel ekspektasi kinerja dengan pernyataan bahwa pengguna kurang setuju atau tidak setuju bila Sistem Pembelajaran Online penggunaanya membutuhkan waktu banyak. Berdasarkan hasil tersebut penggunaan Sistem Pembelajaran Online di SMP Negeri 1 Singaraja dirasa tidak menghambat dan mempermudah sistem belajar mengajar dikelas IX.

Hasil penelitian ini sejalan dengan penelitian [13] Berdasarkan penelitian yang telah dilakukan dapat diambil kesimpulan faktor performance expectation memberikan pengaruh dalam penerimaan pengguna terhadap sistem ERP karena pengguna merasakan manfaat dari sistem ERP, kecocokan sistem ERP dengan pekerjaan mereka, kelebihan sistem ERP dibandingkan sistem sebelumnya, kemampuan ERP dalam memberikan hasil sesuai dengan harapan pengguna, serta peningkatkan kemampuan dan jabatan. Pada penelitian [12] Tabel menunjukkan bahwa tingkat signifikan t uji satu sisi variabel ekspektasi kinerja adalah 0,004 yang lebih kecil dari 0,05 . Hal tersebut berarti H1 diterima, yaitu ekspektasi kinerja berpengaruh positif pada minat penggunaan e-Filing. Ekspektasi kinerja yang dimaksud dalam penelitian ini berhubungan dengan waktu, biaya, kemudahan, kualitas output dan efektivitas individu dalam memenuhi kewajibannya sebagai wajib pajak. Tujuan hipotesis pertama adalah mengetahui pengaruh keyakinan seseorang bahwa dengan menggunakan $e$-Filing dalam pelaporan SPT Tahunannya dapat meningkatkan kinerja dan meningkatkan minat pemanfaatan $e$-Filing. Hasil penelitian yang positif menjelaskan bahwa semakin tinggi tingkat keyakinan wajib pajak dalam penggunaan $e$ Filing akan meningkatkan kinerjanya dalam menyelesaikan 
kewajiban perpajakannya maka semakin besar pula minat wajib pajak tersebut dalam pemanfaatan e-Filin

b. Pengaruh Ekspektasi Usaha terhadap Minat Penggunaan Sistem Pembelajaran Online Edmodo

Ekspektasi Usaha mempunyai nilai t-stastistics sebesar 1,475 yang berarti nilai tersebut dibawah nilai t-tabel 1,96. Nilai $p$-values variabel ekspektasi usaha $(0,141>0,05)$ sesuai hasil tersebut berarti ekspektasi usaha tidak berpengaruh positif Minat Penggunaan. Ini bahwa Ekspektansi Usaha berkaitan dengan kemudahan yang dirasakan pengguna,kerumitan, dan kemudahan penggunaan. Berdasarkan hasil kuisioner yang disebarkan oleh peneliti diperoleh hasil pengukuran pada variable ekpektansi usaha yaitu $14,9 \%$ pengguna sangat setuju, 19,7\% pengguna setuju, 5,8\% pengguna menjawab netral dan $2 \%$ pengguna kurang setuju. Tetapi dari hasil nilai $t$-stastistics sebesar 1,475 dan nilai tersebut masih dibawah nilai t-tabel 1,96. Hal ini disebabkan karena pengguna merasa Sistem tersebut masih rumit digunakan. Pengguna merasa kesulitan untuk memahami apa yang sedang dikerjakan dalam sistem tersebut.

Hasil penelitian ini sejalan dengan penelitian [5] menyatakan bahwa faktor harapan kinerja (performance expectancy) dan harapan usaha (effort expectancy) tidak berpengaruh terhadap niat seseorang untuk bertransaksi di e-commerce $X Y Z$. Hal ini ditunjukkan oleh tidak adanya pengaruh yang signifikan diantara faktor performace expectancy dan effort expectancy terhadap behavioral intention. Pada penelitian [3] mengatakan bahwa ekpektasi usaha memiliki hubungan positif tidak signifikan terhadap minat pemanfaatan sistem informasi dengan koefisien parameter sebesar 0,1081 dan memiliki nilai T statistik lebih kecil dari 1,96, yakni 0,8587. Dengan demikian hipotesis 2 ditolak. Dari hasil olah data menunjukkan bahwa variabel ekspektasi usaha memiliki hubungan positif dan tidak signifikan terhadap minat pemanfaatan sistem informasi. Pada kenyataannya, kemampuan pengguna dalam hal penggunaan sistem informasi belum merata. Selain itu, sistem informasi yang ada juga masih memiliki banyak kendala teknis sehingga menambah waktu bagi pengguna yang belum bisa menggunakan sistem tersebut untuk selalu melakukan penyesuaian agar pekerjaannya dapat sesuai dengan tuntutan prosedur perusahaan.

\section{c. Pengaruh Variabel Pengaruh Sosial terhadap Minat Penggunaan Sistem Pembelajaran Online Edmodo}

Pengaruh Sosial mempunyai nilai t-stastistics sebesar 1.861 yang berarti nilai tersebut lebih dari nilai ttabel 1,96. Nilai p-values variabel pengaruh sosial $(0,063>0,05)$ sesuai hasil tersebut berarti pengaruh sosial tidak berpengaruh positif terhadap Minat Penggunaan. Ini bahwa Pengaruh sosial berkaitan dengan lingkungan sosial di sekitar responden seperti teman kerja, pimpinan, orang tua, pasangan dan organisasi Berdasarkan hasil kuisioner yang disebarkan oleh peneliti diperoleh hasil pengukuran pada variable pengaruh sosial yaitu $13,7 \%$ pengguna sangat setuju, 19,2 \% pengguna setuju, $8 \%$ pengguna netral dan 2,3\% pengguna kurang setuju. Variable pengaruh social tidak berpengaruh positif secara signifikan terhadap minat penggunaan Sistem Pembelajaran Online Edmodo. Hal ini diperkuat dengan pernyataan "Teman - teman saya akan menganggap saya kompeten ketika menggunakan Sistem Pembelajaran Online Edmodo" mendapatkan jawaban dengan nilai paling sedikit.

Hasil penelitian ini sejalan dengan penelitian [6] mengatakan bahwa secara hitungan statistik dengan uji pengaruh diperoleh hasil nilai $\mathrm{p}>0,05$ sehingga variabel social influence tidak berpengaruh secara signifikan terhadap behavioral intention. Berdasarkan hasil penelitian yang dilakukan oleh [2] Menyatakan pada variabel faktor sosial menunjukkan nilai signifikansi sebesar 0,263 ini menunjukkan bahwa faktor sosial tidak berpengaruh secara signifikan terhadap minat pemanfaatan SI karena nilai sig melebihi 0,05, maka hasil ini menolak $\mathrm{H}_{3}$ karena responden merasa bahwa lingkungan sosial di sekitar responden seperti teman sekerja, pimpinan, orang tua, pasangan dan organisasi (atau bahkan tekanan sosial seorang supervisor kepada bawahannya untuk menggunakan TI) tidak mempengaruhi minat mereka dalam memanfaatkan SI, begitu juga dalam status sosial mereka. Hal ini diduga karena perangkat daerah (responden) lebih memiliki minat dalam memanfaatkan SI secara pribadi tanpa harus dipengaruhi oleh lingkungan sekitarnya.

\section{d. Pengaruh Kondisi yang Memfasilitasi terhadap Perilaku Pengguna Sistem Pembelajaran Online Edmodo}

Kondisi yang Memfasilitasi mempunyai nilai $t$ stastistics sebesar 4,315 yang berarti nilai tersebut diatas nilai t-tabel 1,96. Nilai $p$-values variabel kondisi yang memfasilitasi $(0,000<0,05)$ sesuai hasil tersebut berarti kondisi yang memfasilitasi berpengaruh positif terhadap perilaku pengguna. Ini bahwa Kondisi Pemfasilitasi ini berkaitan dengan persepsi dari kondisi yang memfasilitasi penggunaan sistem dan kesesuaian dengan kebutuhan pengguna. Berdasarkan hasil kuisioner yang disebarkan oleh peneliti diperoleh hasil pengukuran pada variabel kondisi pemfasilitasi yaitu sebanyak $6,4 \%$ pengguna sangat setuju, $9,2 \%$ pengguna setuju, $4,2 \%$ pengguna netral $1,8 \%$ pengguna kurang setuju. Variabel kondisi penfasilitasi pernyataan "saya memiliki perangkat yang diperlukan untuk menggunakan sistem pembelajaran online edmodo" hal ini berarti pengguna memiliki perangkat yang memadai untuk penggunaan Sistem Pembelajaran Edmodo tersebut. Sehingga akan mempermudah pengguna dalam mengakses Sistem Pembelajaran Online Edmodo. 
Pada penelitian (Putri \& Mahendra, 2017) mengatakan bahwa facilitating conditions berpengaruh secara positif dan signifikan terhadap perilaku menggunakan (use behavior) Aplikasi Go-jek. Hal ini memiliki arti bahwa kepemilikan sumber daya atau perangkat yang dibutuhkan untuk menggunakan aplikasi transportasi online, seperti smartphone, akan membuat pelanggan di Indonesia meningkatkan frekuensi menggunakannya. Pada penelitian [3] mengatakan bahwa kondisi yang memfasilitasi memiliki hubungan positif signifikan terhadap penggunaan sistem informasi dengan koefisien parameter sebesar 0,4778 dan memiliki nilai $\mathrm{T}$ statistik lebih besar dari 1,96, yakni 5,2961. Dengan demikian hipotesis 4 diterima. Dari hasil olah data menunjukkan bahwa variabel kondisi-kondisi yang memfasilitasi memiliki hubungan positif dan signifikan terhadap penggunaan sistem informasi.

\section{e. Pengaruh Minat Penggunaan terhadap Perilaku Pengguna Sistem Pembelajaran Online Edmodo}

Minat Penggunaan mempunyai nilai $t$-stastistics sebesar 7,874 yang berarti nilai tersebut diatas nilai t-tabel 1,96. Nilai p-values variabel Minat Penggunaan $(0,000<0,05)$ sesuai hasil tersebut berarti Minat Penggunaan berpengaruh positif terhadap perilaku pengguna. Ini bahwa Besar pengaruh variabel minat penggunaan terhadap perilaku pengguna sesuai nilai original sample yaitu 0,577 sehingga variabel minat pemanfaatan mempengaruhi variabel perilaku pengguna sebesar $57,7 \%$. Pada pernyataan minat penggunaan yang memiliki nilai terbesar yaitu "Saya akan terus mencoba menggunakan Sistem Pembelajaran Online Edmodo". Ini berarti bahwa pengguna yang bersedia menggunakan Sistem Pembelajaran Online Edmodo itu akan berdampak pada perilaku penggunaan layanan di masa mendatang.

Hasil penelitian ini sejalan dengan penlitian [7] hasil menunjukkan bahwa niat untuk menggunakan Exelsa memiliki hubungan dengan penggunaannya. Korelasi yang positif dan signifikan antara behavioral intention dengan use behavior $(\mathrm{r}=0.161$; $\mathrm{p}$-value $<0.05)$. Temuan ini sesuai dengan konsep dasar dari model-model penerimaan pengguna yaitu, niat untuk menggunakan teknologi informasi akan mempengaruhi penggunaan sebenarnya teknologi informasi tersebut. Pada penelitian yang berjudul [1] Dalam penelitian ini, Behavioral Intention memiliki pengaruh positif dan signifikan terhadap Use Behavior, dengan $T$-value sebesar 12.70. Ini berarti bahwa semakin banyak pengguna yang bersedia menggunakan layanan transportasi online, itu akan berdampak pada penggunaan layanan di masa mendatang.

\section{REKOMENDASI}

Berdasarkan hasil yang telah di dapat dalam penelitian ini, ada beberapa rekomendasi yang peneliti usulkan dan beberapa masukan dari responden berikan yakni :

1. Ekspektasi kinerja berpengaruh secara positif terhadap minat pemanfaatan Sistem Pembelajaran Online Edmodo. Dari pernyataan pada kuisioner terkait indikator kesesuaian pekerjaan dimana pengguna percaya bahwa sistem memiliki kemampuan untuk meningkatkan kinerja ketika melakukan proses belajar mengajar. Ekspektasi usaha dan pengaruh sosial tidak berpengaruh positif terhadap minat penggunaan Sistem Pembelajaran Online Edmodo. Berdasarkan hasil tersebut maka peneliti tidak memberikan rekomendasi terkait tentang ekpektansi usaha yang meliputi indikator kemudahan yang dirasakan pengguna, kerumitan, serta kemudahan penggunaan Sistem Pembelajaran Online Edmodo.

2. Kondisi yang memfasilitasi berpengaruh positif terhadap perilaku penggunaan Sistem Pembelajaran Online Edmodo. Rekomendasi yang peneliti berikan yaitu terkait pentingnya fasilitas yang sangat membantu dalam proses penggunaan Sistem Pembelajaran Online Edmodo dari pihak sekolah harus menyediakan fasilitas yang memadai seperti jaringan internet ataupun komputer sehingga akan memudahkan siswa serta guru tersebut saat mengakses Sistem Pembelajaran Online Edmodo.

\section{KESIMPULAN}

Berdasarkan hasil analisis dan pembahasan maka dapat disimpulkan penilitian sebagai berikut :

1. Ekspektansi Kinerja berpengaruh positif terhadap minat penggunaan Sistem Pembelajaran Online Edmodo dengan nilai t-statistic 2,609. Hal ini membuktikan bahwa pengguna percaya dengan menggunakan sistem tersebut akan mempermudah sistem pembelajaran di kelas IX SMP Negeri 1 Singaraja, selain itu pengguna juga percaya bahwa dengan menggunakan Sistem Pembelajaran Online Edmodo dapat meningkatkan hasil belajar siswa khususnya kelas IX. Sedangkan variabel Ekspektasi usaha dan pengaruh sosial tidak berpengaruh positif terhadap minat penggunaan Sistem Pembelajaran Online Edmodo hal ini dibuktikan dengan hasil analisis nilai $t$-statistics secara berurutan yaitu 1,475 dan 1,861 lebih kecil dari nilai $t$-tabel yaitu 1,96 hal ini disebabkan karena Sistem Pembelajaran Online Edmodo masih sulit untuk digunakan dan diterapkan dalam sistem pembelajarandi SMP Negeri 1 Singaraja. 
2. Kondisi yang memfasilitasi berpengaruh positif terhadap perilaku penggunaan Sistem Pembelajaran Online Edmodo memiliki nilai $t$-statistics sebesar 4,315 lebih besar dari nilai t-tabel yaitu 1,96. Pengguna merasa bahwa fasilitas yang ada sangat mendukung penggunaan Sistem Pembelajaran Online Edmodo serta jaringan internet juga sangat membantu pengguna dalam mengoperasikan Sistem Pembelajaran Online Edmodo Sedangkan pada Minat penggunaan juga berpengaruh positif terhadap perilaku pengguna Sistem Pembelajaran Online Edmodo dengan nilai t-statistics sebesar 8,973 lebih besar dari nilai t-tabel yaitu 1,96. Pengguna berniat untuk terus menggunakan Sistem Pembelajaran Online Edmodo dalam melakukan pekerjaanya, sehingga dari niat tersebut mencerminkan pengguna akan terus menggunakan Sistem Pembelajaran Online Edmodo.

Berdasarkan hasil penelitian yang telah dilakukan, analisis penerimaan Sistem Pembelajaran Online Edmodo Menggunakan Model Unified Theory of Acceptance and Use of Technology Studi Kasus : Kelas IX di SMP Negeri 1 Singaraja memiliki potensi untuk dikembangkan menjadi lebih baik lagi. Oleh karena itu, peneliti mencoba memberikan saran yang sekiranya dapat berguna untuk peneltian selanjutnya, antara lain :

Untuk pengelola Sistem Pembelajaran Online Edmodo, peneliti berharap sekolah mau memberikan arahan kepada setiap guru atau siswa untuk menerapkan penggunaan Sistem Pembelajaran Online Edmodo dalam proses belajar mengajar. Karena dengan menggunakan sistem pembelajaran secara online mampu meningkatkan efektifitas belajar siswa. Untuk penelitian selanjutnya berdasarkan rekomendasi yang peneliti berikan, peneliti berharap mampu melanjutkan rekomendasi tersebut agar Sistem Pembelajaran Online Edmodo semakin optimal dalam penggunaanya.

\section{REFERENSI}

[1] Achmad Fauzi1, Teguh Widodo, T. D. (2018). Pengaruh Behavioral Intention Terhadap Use Behavior Pada Penggunaan Aplikasi Transportasi Online ( Studi Kasus Pada Pengguna Go-Jek Dan Grab Di Kalangan Mahasiswa Telkom University ), (October).

[2] Ellyana, D. D., Redy, A., \& Hamzah, A. (2009). Variabel Anteseden Dan Konsekuensi Pemanfaatan Sistem Infoemasi ( Studi Emperis Pada Pemerintahan Kabupaten Di Pulau Madura ), 6, 71-88.

[3] Hartono, W. A., \& Meiranto, W. (2013). Pengaruh Pemanfaatan Dan Penggunaan Sistem Informasi Terhadap Kinerja Individu, 2, 1-10.
[4] Howard, R., Restrepo, L., \& Chang, C.-Y. (2017). Addressing Individual Perceptions: An Application Of The Unified Theory Of Acceptance And Use Of Technology To Building Information Modelling. International Journal Of Project Management, 35(2), 107-120.Https://Doi.Org/10.1016/J.Ijproman.2016.10.012

[5] Mustaqim, R. N., Kusyanti, A., \& Aryadita, H. (2018). Analisis Faktor-Faktor Yang Memengaruhi Niat Penggunaan E-Commerce Xyz Menggunakan Model Utaut ( Unified Theory Acceptance And Use Of Technology ), 2(7), 2584-2593.

[6] Nurus Sa'idah. (2017). Analisis Penggunaan Sistem Pendaftaran Online (E-Health) Berdasarkan Unified Theory Of Accepptance And Use Of Technology (Utaut, 5, 72-81.

[7] Nyoman, I. G., \& Wisnu, S. (2009). Penerapan Model Utaut Untuk Memahami Penerimaan Dan Penggunaan Learning Management System Studi Kasus: Experiental E-Learning Of Sanata Dharma University. Sistem Informasi, 5, 114-120. Retrieved

From

Http://Jsi.Cs.Ui.Ac.Id/Index.Php/Jsi/Article/View/271

[8] Santosa, P. I. (2018). Metde Peelitia Kuantitatif. Yogyakarta: Cv. Andy Offset.

[9]Santoso, P. I. (2018). Metode Penelitian Kuantitatif Pengembangan Hipotesis Dan Pengujiaannya Menggunakan Smartpls. Yogyakarta: Penerbit Andi.

[10] Sugiyono. (2010). Metode Penelitian Pendidikan Pendekatan Kuantitatif, Kualitatif, Dan R\&D. Bandung: Alfabeta.

[11] Venkatesh, V., Morris, M. G., Davis, G. B., \& Davis, F. D. (2003). User Acceptance Of Information Technology: Toward A Unified View Author ( S ): Viswanath Venkatesh, Michael G . Morris , Gordon B . Davis, Fred D . Davis Published By: Management Information Systems Research Center, University Of Minnesota, 27(3), 425-478.

[12] Wulandari, N. P. A., \& Yadnyana, I. K. (2016). Penerapan Model Unified Theory Of Acceptance And Use Of Technology Di Kota Denpasar, 1270-1297.

[13] Yulianti, \& Handayani, P. W. (2013). Analisis Faktor-Faktor Yang Memengaruhi Penerimaan Pengguna Dalam Menggunakan Sistem Erp Dengan Studi Kasus Pt Xyz, 69-75. 